\title{
Synthesis
}

\section{Scenarios for Resilient Shrimp Aquaculture in Tropical Coastal Areas}

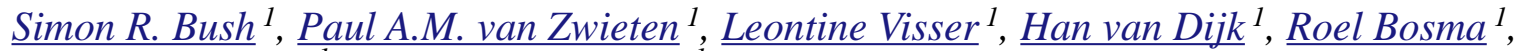 \\ Willem F. de Boer $^{l}$, and Marc Verdegem ${ }^{1}$
}

\begin{abstract}
We contend there are currently two competing scenarios for the sustainable development of shrimp aquaculture in coastal areas of Southeast Asia. First, a landscape approach, where farming techniques for small-scale producers are integrated into intertidal areas in a way that the ecological functions of mangroves are maintained and shrimp farming diseases are controlled. Second, a closed system approach, where problems of disease and effluent are eliminated in closed recirculation ponds behind the intertidal zone controlled by industrial-scale producers. We use these scenarios as two ends of a spectrum of possible interactions at a range of scales between the ecological, social, and political dynamics that underlie the threat to the resilience of mangrove forested coastal ecosystems. We discuss how the analytical concepts of resilience, uncertainty, risk, and the organizing heuristic of scale can assist us to understand decision making over shrimp production, and in doing so, explore their use in the empirical research areas of coastal ecology, shrimp health management and epidemiology, livelihoods, and governance in response to the two scenarios. Our conclusion focuses on a series of questions that map out a new interdisciplinary research agenda for sustainable shrimp aquaculture in coastal areas.
\end{abstract}

Key Words: coastal fisheries; governance; livelihood decision making; mangrove; shrimp-aquaculture; social-ecological systems; South-East Asia; trans-disciplinary research; WSSV disease

\section{INTRODUCTION}

Penaeid shrimps (Litopenaeus vannamei and Peneaus monodon), which comprise around $80 \%$ of total farmed shrimp production (FAO 2009), have emerged as one of the most valuable, globally traded aquaculture products, as well as one of the most emotive and politically polarizing production systems in coastal areas (Stonich and Bailey 2000, Béné 2005, Vandergeest 2007). The enormous growth of shrimp production from 1,600 $t$ in 1950 to close to 4.5 million $\mathrm{t}$ in 2006 at a value of just under US $\$ 18$ billion (FAO 2009) has been achieved with a concurrent reduction in mangrove area in some countries of between 50 to $80 \%$, leading to considerable loss of biodiversity and coastal ecosystem function (Valiela et al. 2001, Alongi 2002, Manson et al. 2005b). The most severe damage coincided directly with the rapid expansion of shrimp production during the 1990s (Primavera 1997, Hall 2004). In the 2000 s overall productivity has continued to grow, but at a lower rate, largely due to the higher incidence of disease and, in a number of countries, the lower productivity of extensive farming systems (Vaiphasa et al. 2007). The 'boom crop' nature of shrimp production (see Hall 2003) has meant that the promise of high returns on investment has gradually been tempered by riskier returns in global markets and increasing levels of social and ecological uncertainty and vulnerability.

The global nature of shrimp trade has also meant that these uncertainties and vulnerabilities emerge at the complex intersection of changing international market conditions, such as food safety and quality standards, and ecological feed-back mechanisms, such as disease incidences and epidemics (Kautsky et al. 2000, Barbier and Cox 2004, Oosterveer 2006). Conversely, the resilience of shrimp culture systems, broadly defined as the capacity to maintain their integrity when responding to external changes and feedbacks within their wider coastal social-ecological systems (Holling 2001, Folke 2006), is therefore codetermined by a multitude of decisions made by producers and 
fishers in relation to economic, political, and ecological conditions at a range of scales. How producers make decisions related to livelihoods and production is therefore dependent on an interrelated set of local to global institutions, as well as by their ability to adapt to changes in the natural resource base of the aquatic production systems.

The specific details of the boom in shrimp aquaculture differ considerably among countries, but the challenges that farmers face, in terms of production risks, have gradually converged (Lebel et al. 2002, Hall 2004). International demand for shrimp in international markets is unlikely to abate as many economic forecasts predict an increase in the consumption of shrimp in the mid to long-term that can only be met by aquaculture. As a result of the 'sustainable seafood' debates in the US and EU (e.g., Iles 2007, Bush 2010), a shift from confrontation to active engagement with the industry has taken place, largely through the development of a range of national state and global private production standards (Béné 2005, Vandergeest 2007). These standards have taken a number of forms, ranging from the FAO Code of Conduct for Responsible Aquaculture and the Network of Aquaculture Centres in Asia-Pacific's (NACA) Best Management Practices, to country specific standards, such as Thai Quality Shrimp, retail owned quality standards, such as GlobalG.A. P., and finally NGO-led initiatives, such as WWF's Shrimp Aquaculture Dialogue, which will feed into the newly established Aquaculture Stewardship Council (Corsin et al. 2007, WWF 2007). There is considerable variation between the standards, but all have the common goal of organizing the multitude of uncertainties associated with shrimp production into verifiable metrics that can be translated into risk management.

We contend that the rise of the sustainable seafood debate and global proliferation of quality standards has led to essentially two opposing scenarios emerging over how best to manage shrimp production in order to ensure both social and ecological resilience in coastal areas. The first is that shrimp aquaculture is integrated into intertidal landscapes so that the ecological functions of coastal mangroves are maintained, diseases controlled, and production kept in the hands of poorer small-scale producers who make up the majority of production (Fitzgerald 2002, Primavera 2006, Vandergeest 2007, Islam 2009). The second scenario entails closing the aquaculture system to the surrounding environment thereby eliminating the flow of effluent and spread of disease, as well as locating production behind the intertidal zone, thereby avoiding alteration of estuarine and mangrove habitats (Boyd and Clay 2002, FAO et al. 2006, Phillips 2006). A consequence is that given the generally high investment needed for these systems, small-scale producers are unlikely to participate.

The two scenarios are not mutually exclusive alternatives but rather the ends of a spectrum of contested ideas around current effects of and solutions to shrimp production in coastal ecosystems. The following first elaborates these scenarios as an entry point from which to start understanding the scaled interaction between the ecological, social, and political dynamics that pose possible threats to the resilience of mangrove forested coastal ecosystems. We then identify key concepts that contribute to our analytical toolkit such as resilience, uncertainty, and risk, as well as the organizing heuristic of scale, and explore how they can contribute to an interdisciplinary understanding of sustainable use and management of coastal resources. This is followed by an integrated assessment of the scenarios by identifying the linkages and feedback between four empirical social-ecological dynamics: (1) mangrove ecosystems and estuarine fisheries, (2) shrimp disease and pond management, (3) local livelihood decision making, and (4) state and market governance arrangements. Together these dynamics and concepts help us to develop a framework for elaborating the complex interactions between ecological and societal processes and their influence over governing shrimp production to either landscape integrated or closed system approaches.

\section{COASTAL AQUACULTURE SCENARIOS}

\section{Landscape integrated systems}

Small-scale shrimp aquaculture systems are an important source of nutrition and income for coastal communities. A way of ensuring their sustainability is to integrate them into the mangrove and estuarine habitats. Silvofisheries, a form of low-input aquaculture that integrates mangrove tree culture with brackish water aquaculture, offers such a scenario. Two basic models of silvofisheries exist with mangroves either within or outside the pond system at specific pond-mangrove area ratios; a 
variety of designs exist across Southeast Asia (Fitzgerald 2002). All systems attempt to balance conservation issues with optimizing economic profitability (Primavera 2000). Hatchery reared seed is often supplemented with low-input farming techniques such as allowing natural recruitment of wild juveniles through tidal flushing. Expected benefits of landscape integrated systems include minimization of contamination by pond effluents of the coastal ecosystem, provision of higher quality supply of water for shrimp farming, and the maintenance of coastal fisheries.

In integrated forestry-fisheries-aquaculture systems, mangroves function as biofilters for pond effluents (Vaiphasa et al. 2007). Farm density is important so as to not exceed the capacity of the environment to assimilate waste flushed from the ponds during low tide. Mangroves adjacent to intensive ponds can be used to process nutrients from pond effluents. Mangroves inside ponds can play a similar role, but in addition provide shading and food for shrimps and fish (Primavera and Esteban 2008). In landscape integrated systems, the inflow of pathogens through surrounding tidal water cannot be avoided. Farmers may stock specific pathogen free (SPF) post-larvae to reduce disease risks. Diseases may be controlled by optimizing seasonal environmental conditions such as temperature and salinity, next to hygiene, nutrition, and feeding. Increased incidence of White Spot Disease (WSD) of shrimp, a disease caused by a virus officially known as White Spot Syndrome Virus (WSSV; Vlak et al. 2005), is associated with both low and high water temperature, suboptimal salinity and $\mathrm{pH}$, heavy rainfall, and presence of carrier organisms in pond, water, or feed. On the one hand, suboptimal conditions weaken the immune response of shrimp, and on the other hand, the load of viruses and other harmful bacteria changes under influence of environmental and management conditions (Phuoc et al. 2009, Tendencia et al. 2009). Recent research showed that mortality due to WSSV increases in presence of Vibrio (Phuoc et al. 2009). Ageing pond soils gradually become more reduced, accumulate toxic compounds, and acidify (Avnimelech and Ritvo 2003). During culture, wastes accumulate faster than the amount mineralized, making it necessary to dry and oxidize the pond bottom between culture cycles. Harrowing or ploughing of the pond bottom accelerates this process (Beveridge et al. 1994).

As mangroves play an important role as a nursery area for coastal fishes (Mumby et al. 2003, Manson et al. 2005b), the integration of ponds with mangroves in intertidal zones is seen as a means of maintaining the productive capacity of nearby coastal fisheries without compromising the productivity of shrimp aquaculture. These 'ecologically integrated' mangrove-friendly aquaculture technologies are amenable to small-scale, familybased operations and are also accessible to poorer members of coastal communities who have only limited access to finance and are largely dependent on open-access resources (Luttrell 2006). In addition, dispersed trade and processing industries absorb a large number of poor rural producers, especially women (Islam 2009). By leaving these producers to operate within the mangroves, their already vulnerable livelihoods are supplemented with potentially appropriate aquaculture technologies that can contribute to the sustainable development of coastal areas. Landscape integrated systems may therefore have the potential to support coastal ecosystem conservation while maintaining highincome potential shrimp aquaculture for coastal communities (Binh et al. 1997, Macintosh 1998).

The complex nature of these production systems may require both state regulation and private certification to develop methodologies for monitoring and evaluating their ongoing performance. Some efforts have been undertaken to formulate codes of conduct and private standards governing the area of mangrove inside and outside ponds, health and safety requirements, and levels of chemical pesticide use for sustainable use of mangrove and adjacent coastal areas (e.g., ACC 2005, Bagarinao and Primavera 2005, GlobalG.A. P. 2007). For these initiatives to be successful it is increasingly recognized that state and private institutions need to supplement existing customary arrangements with microfinance and new technical capacities and technologies. Furthermore, the success of such initiatives is dependent on coastal communities being rewarded through either improved market access or price premiums for niche organic, fair trade, or environmental friendly products.

\section{Closed systems}

One way to minimize the negative effects of shrimp aquaculture on coastal mangroves and wetlands is to invest in super-intensive, closed recirculation systems and move ponds out of the intertidal zone. Production in these systems ranges from less than 
$8,000 \mathrm{~kg} / \mathrm{ha}$ to more than $20,000 \mathrm{~kg} / \mathrm{ha}$ per crop (Otoshi et al. 2009). Such high production per unit area without water exchange presents several advantages over conventional shrimp aquaculture, including greater potential for mechanization, fewer logistical problems in pond operations, and less effluent. Closed systems also enable better control of disease in broodstock and more efficient use of water through effective waste water treatment (Kongkeo 1997). Because these intensive systems are not located in mangrove and estuarine areas, coastal environments are maintained and the productivity of coastal fisheries is no longer directly influenced by shrimp farm activities.

Only very recently, intensive shrimp-culture recirculation systems have become commercially viable (Otoshi et al. 2006). Basic elements that appear to be crucial to the success of these systems include: small lined ponds, aeration, and disease resistant strains of omnivorous shrimp species. Some intensive systems operated in various Southeast Asian countries also have limited water exchange and attempts have been made to close them to the surrounding environment, including the influence of large temperature changes caused by exposure to sun and rain (Kongkeo 1997). Although closed recirculation systems are, with few exceptions, operated as pilot operations, their higher efficiencies have led Boyd and Clay (2002) to suggest that if they are "... suitable for general adoption by shrimp producers around the world, [they] could provide a more environmentally responsible method of shrimp production."

Because of the high cost of investment required, small-scale shrimp producers are less likely to be able to participate, thereby significantly reducing the proliferation of shrimp ponds built on marginal land in intertidal mangrove forests. Producers that are able to adopt these intensive practices could benefit from more stable production output as a result of improved disease, feed, and broodstock management. At a societal level, the disruption to existing coastal livelihoods would be offset by the improved reliability of intensive shrimp production, which would increase global competitiveness and provide a source of foreign export exchange (FIAS 2006). New employment opportunities could also arise in these farms as well as in processing companies, while other employment could be generated through coastal restoration programs. Given the continued growth of the sector, these intensive systems could lead to the improved well- being of coastal communities by decreasing the destructive development of extensive pond culture in coastal areas.

By promoting closed-system production, governments would need to reallocate agricultural land for shrimp production and, with the assistance of companies and NGOs, facilitate the transfer of required aquaculture technologies and techniques. A significant burden would be placed on governments to relocate coastal shrimp farmers who are moved out of shrimp production and establish alternative livelihood programs outside of mangrove areas. Because of the large venture capital needed and the tendency for vertical integration in largely transnational companies, the state's role would be to facilitate investment (Neiland et al. 2001). Certification would play an increasingly important role in restructuring the shrimp industry, rewarding more streamlined and higher quality shrimp production with access to lucrative European and North American markets.

\section{ANALYZING SOCIAL-ECOLOGICAL SYSTEMS}

The two scenarios challenge us to think about the key dynamics that influence the sustainability of shrimp production, but offer little analytical power by themselves. This section discusses resilience and the associated concepts of uncertainty, risk, and complexity, focusing on the analytical power they hold for understanding the potential of landscape integrated and closed-systems for ecosystems and livelihoods in coastal areas. Reducing the uncertainty and risk of resource users and rebuilding the resilience of social-ecological systems have emerged as key normative objectives for responsible management of coastal areas (Nicholls and Branson 1998, Adger et al. 2001). To structure how, where, and through whom these objectives might be reached, the analytical heuristic of scale is also introduced to help organize and elaborate the complexity of coastal areas, including what might be seen as multiple 'resiliences' that can be described when zooming in from landscapes to single units such as fishers and producers, ponds, mangrove forests, and estuaries.

Resilience has emerged from the ecological concepts of complexity, co-evolution, and multiple equilibria (Odum 1975, Norgaard 1994, Holling 2001, Costanza 2003) to provide an integrative 
theory for understanding combined socialecological systems. The theory emerged through recognition that more than one steady state or equilibrium can exist in a specified system and has led to the study of the shifts and responses to internal and external drivers of system change (Holling 1973). The resilience perspective has led researchers to focus on the magnitude of external disturbances to a system that can be absorbed or buffered without leading to fundamental changes of its functional, human and nonhuman, characteristics (Berkes et al. 2003). The theory is now being used to understand the capacity of social-ecological systems to absorb recurrent disturbances by examining how interactions, processes, and feedbacks inhibit or facilitate change from one system state to another (Adger et al. 2005, Folke 2006).

The concept of resilience has evolved from the technical and ecological sciences to engage and incorporate social systems. Technical or 'engineering resilience' focuses on the efficiency of a system to return to a stable state. Ecologists have largely focused on the robustness of systems to buffer themselves from shock and disturbance or adaptively realign themselves into different states (Folke 2006). Social resilience has been described as the capacity of humans, either individual or communities, to withstand external shock from wider economic, political, or cultural perturbations (Adger 2000). Berkes and Folke (1998) demonstrate, through an analysis of natural resource management practices, that the social and the ecological mutually constitute each other through processes of interaction. Change is an inherent property of this interaction from which new patterns emerge. This two-way interaction requires a breakdown of the distinction between the two domains. In doing so the concept of resilience not only highlights the effect of human activities on ecosystems, and vice-versa, but also the memory, learning, and purposive adaptation of socialecological systems that are necessary for transformation and innovation (Walker et al. 2004).

Central to understanding the resilience of a complex social-ecological system is the identification of the components that enable self-organization and adaptation in response to risk factors that force changes in the stability or integrity of both social and ecological systems (Folke et al. 2002, Adger et al. 2005). Self-organization is predominantly an ecological concept that is used, for example, to understand how diversity, aggregation, and endogenous formation can enhance opportunities for a system to adapt (Levin 1998). Understanding society in a similar way has faced resistance from those who believe it naturalizes complex social processes and ignores notions of risk, uncertainty, and the agency of social actors to make decisions (Nadasdy 2007). Decision making may therefore be better understood, according to Lebel et al. (2006), as the capacity to cope with uncertainty, the openness to learning, the acceptance of the inevitability of change, and the ability to treat any intervention as experimentation or 'adaptive management'. The challenge then becomes to institutionalize the 'adaptive capacity' within a social-ecological system by supporting collaboration, pluralism, and linkages between multiple types of stakeholders, diversity of interests represented, multiple perspectives on the problem domain, and connections across multiple scales and levels (Armitage et al 2008). Resilient systems are therefore not only those which have the capacity to maintain their functional interactions, but rather those that have the ability to adapt to external change and evolve through learning. Conversely systems unable to maintain functional interactions and a poor capacity for institutionalized learning may have very little capacity to respond to external pressure.

The resilience of a system is closely related to the temporal and spatial scale at which it is defined. Although socially constructed and relational, i.e., dependent on human observation (Howitt 1998), the choice of scale provides observers a framework with which to order the temporal and spatial characteristics of a system, including its' selforganizing or institutionalized adaptive capacities. Furthermore, the scales of organization within a system define the relationships between the parts that constitute and distinguish the whole (Cash and Moser 2001). For example, to distinguish between various interacting processes, observational units for the transmission of WSSV are defined between shrimp in ponds, between shrimp ponds in a coastal area, and as an epidemic across regions such as Southeast Asia. Each scale has its own constituent level of resilience against infection. Observations at one scale find their explanation in processes at smaller scales, yet are contained in and constrained by processes at higher levels within coastal socialecological landscapes and beyond to global processes (Armitage and Johnson 2006). Recognizing the possibility of multiple 'resiliencies' at a range 
of temporal and spatial scales enables us to distinguish sets of internal and external social and ecological factors influencing shrimp aquaculture development in coastal environments.

Understanding self-organization and adaptation to pressures emanating from interdependent scales is a useful framework for understanding complex social-ecological systems, but only provides a partial view when analyzing processes of change. The landscape and closed system scenarios are by definition normative, i.e., based on the agency of competing values and claims of relevant actors. Understanding ecosystem change in its wider spatial and temporal context therefore requires understanding how individual and collective decisions are made in response to decisions about uncertainty and risk. Single events of change can then be understood with reference to the level from which it originates and the scale at which it operates. In order to understand and predict local changes in coastal fish or shrimp communities it is therefore necessary to understand the source of these risks, how they are communicated through social, economic, cultural, and political networks, how they influence decision making, and finally, what influence they have over the resilience of social-ecological systems.

\section{SHRIMP AQUACULTURE AS A COMPLEX SOCIAL-ECOLOGICAL SYSTEM}

We will now turn to a discussion of the landscape integrated closed aquaculture system scenarios as complex social-ecological systems. Resilience, uncertainty, and risk are used to understand these two scenarios with respect to (1) the interaction between coastal landscapes and shrimp farming, and (2) the management of shrimp disease; and social processes of decision making in the context of (3) coastal livelihoods, and (4) governance.

\section{Shrimp farming as a landscape forming practice}

Four observations are often reiterated and illustrated in the general and scientific literature on the use of mangrove ecosystems by shrimp aquaculture: (1) pond systems remove mangrove forests and with that impact, populations of marine and estuarine organisms; (2) water pollution from ponds negatively effects adjacent mangrove ecosystems; (3) shrimp farming depends on wild stocks of gravid females; and (4) the increased incidence of WSD has led to the abandonment and extension of ponds in new mangrove areas. However, these observations give limited guidance to whether and at what scale shrimp farming can be successfully integrated to maintain ecological functions in mangrove forest landscapes. Correlations over large scales suggest ecological patterns of linkages between mangroves and coastal benthic and pelagic systems, while detailed knowledge of ecological processes is available for some parts of the mangrove ecosystem, in particular the benthic habitats of the forests. However, the ability to scale down processes established at large scales or scale up patterns observed at small scales through these ecological studies to the scale of landscapes is tenuous at best and the strength and spatial scale of the linkages between mangroves with coastal ecosystems is largely unresolved. This is problematic as it is at the landscape scale that decisions are to be made on the integration of shrimp farming in coastal ecosystems.

Mangrove conversion for shrimp culture represents a trade-off with coastal fisheries production as mangrove forests are considered critical nursery habitats for the juvenile stages of commercially important species of fish and invertebrates. At large spatial scales (>100-1000 km) linkages between mangrove extent and coastal fisheries production for penaeid shrimp have been detected through correlative approaches (Manson et al. 2005a, Manson et al. 2005b). However, there is little reliable empirical evidence that a reduction in the functions of mangrove ecosystems results in lower coastal fisheries production (Mumby et al. 2003). Reliable predictions of the implications of habitat loss or degradation on animal populations and fisheries production at smaller spatial scales $(<100$ $\mathrm{km}$ - estuarine catchments) are difficult because of the current limited understanding of habitat connectivity within coastal landscapes (van Zwieten et al. 2006). As fish use multiple habitats in the coastal zone, the loss or degradation of one type of habitat is likely to influence the value of the others. Therefore, size, location, and connectivity of habitats that support fish resources are important elements in considering the relationship with production and recruitment to fisheries.

Tides, waves, and currents, as well as the spatial and temporal dimensions of disturbance, all play a role in the extent to which estuarine areas can rehabilitate. Undisturbed estuaries have large areas 
with oxidized sediments, whereas ponds in the same areas always have reduced sediments with considerably altered benthic communities. The combination of these changes means that abandoned ponds are rarely taken back into production again, regardless of farming strategies such as fallowing. Although there is evidence that within 12 years after rehabilitation with a single mangrove tree species benthic communities are able to return to states indistinguishable from natural forest reserves (Macintosh et al. 2002), there has been limited experience with soil rehabilitation over larger scales and shorter time periods. A range of questions remain about the relationship between shrimp aquaculture, tidal flows, benthic communities, and the resilience of soils to regenerate. These include: the effect of closing off an estuarine soil from tides and waves for shrimp culture on benthic communities; the effects of farm management on the structure and development of benthic communities both within and outside ponds; the feedbacks from the benthic community to the estuarine soil and forests through burrowing, recycling, and filtering; and an understanding of the temporal and spatial scale of the reversibility of effects.

Mangrove ecosystems can fulfill their key role in shrimp farming and as coastal nurseries for fisheries even when large parts of the forest have disappeared. For instance, Loneragan et al. (2005) describe stable landings of shrimp in areas of Malaysia where mangrove had been maintained as well as increases in landings in adjacent areas of degraded mangroves, perhaps because of migration of prawns from adjacent areas. Thus at a larger scale, the mangrove ecosystem can be viewed as being built up from subsystems or areas that 'switch' between alternative states of degraded soils with no trees to forested land with stable ecosystem functions. At a lower spatial scale these components are merely adjacent to each other. At the higher scale the spatial arrangements of the components within the system becomes important. Indeed, the spatial arrangement and the total area covered by shrimp ponds affect the key role mangroves have in supporting the shrimp industries and the local fisheries. In fact, low levels of fragmentation might even increase fish catches (Hindell and Jenkins 2005), indicating that a spatially explicit analysis is required before prediction can be made (Eggleton et al. 2004, Pittman et al. 2004). The spatial configuration and the extent of the different components of the ecosystem are thus important attributes in analyzing the ecological resilience of coastal marine communities at various scales in a landscape integrated mangrove forest-shrimp farming system.

In the closed system scenario, the mangrove ecosystem gets taken out of the equation. Linkages between shrimp farming and coastal ecology will still exist but at a distance from the actual production system, as for instance: the fisheries for gravid females; the possibilities for crustacean diseases to enter the culture system from the wild and the fish meal required for shrimp feed. However, when the reproductive cycle of shrimp gets closed and genetically modified disease resistant strains of shrimp are developed, the first two linkages will disappear.

\section{Disease management of shrimp production systems}

The resilience of a production system is dependent on the ability of a producer to reduce a system's exposure to disease vectors and to manage environmental factors so that the capacity of the shrimp to co-exist with the pathogen is maximized. Broader environmental conditions such as temperature, dissolved oxygen, salinity, soil condition, influence vulnerability to diseases both as stress factors for shrimp, reducing its defense mechanisms, and as determinants of virulence and transmission of pathogens (Lightner et al. 1998). Evidence indicates that populations of wild organisms such as crustaceans, insect larvae, copepods, and polychaetes in tropical coastal areas act as a reservoir for infectious diseases (Flegel 2006). Given the high motility of these wild populations they may also act as an effective vector of the disease between ponds and also between unconnected coastal areas. The resilience of production systems is therefore dependent on: (1) the isolation of a system from a disease, (2) its internal resistance once it has been infected, and (3) secondary risks associated with management measures to decrease their vulnerability. In case of WSSV, this also requires further details on the etiology of the disease, the effect it has on production, as well as the specificity of the tests to detect it to define resilience.

The total exclusion of pathogens is technically difficult and expensive, and though closure reduces the risk of infection it does not mean the system has a higher resilience to catastrophic change should a 
pathogen enter. As known from a range of intensive systems, including pigs and poultry, the internal capacity or 'self-organization' to respond to diseases is small and infection with a pathogen can lead to catastrophic mortality. Conversely, open production systems, in which shrimp are continuously exposed to a diversity of organisms, may have a higher capacity to adapt to the stress from diseases, reducing the probability of complete stock loss, though the evidence for the rescue effect of diversity is small (Suzan et al. 2006, 2008). However, in dense cultivation areas this potential tolerance is offset by the higher risk of direct transmission through wild populations of macroinvertebrates, soil, or water exchange.

Soil structure in ponds is an important environmental factor affecting shrimp health as shrimp live in sediments during a large part of their life-cycle. As in agriculture, pond soils can be partially managed through water exchange, mixed cropping, fallowing, harrowing, drying, and sediment removal. However, over time all aquaculture ponds accumulate sediments in the form of a flocculent layer of varying thickness that can be considered as a microbiological laboratory with an oxygen gradient that is more or less fully oxidized at the top and highly reduced at the bottom. Shrimp health and resistance to pathogens seems highly dependent to changes in this flocculent layer, in particular the main cultured species Macrobrachium rosenbergii, Litopenaeus vannamei, and Penaeus monodon. Each of these species exhibits specific behavior and tolerance to adverse water quality in relation to the flocculent layer. Although difficult to standardize measurements to assess effects on shrimp health and productivity, it appears that shrimp avoid low oxygen areas requiring measures to reduce sediment development (Meijer and Avnimelech 1999). Disease risks can be further reduced by appropriate soil management measures between harvests when ponds are emptied of water (Yu et al. 2006).

Risk management relates to both the producers' knowledge about aspects of a production system that are likely to increase the exposure to infection, and the cost and benefits of management in order to prevent a disease outbreak. Maintaining soils, choosing temperature to stock and harvest, and understanding the seasonal nature of the incidence of pathogens in the wild populations of mobile organisms such as crabs, macroinvertebrates, and wild shrimp, are some of the management aspects.
Closed systems may be less vulnerable to infection, but the probability of infection has to be weighed against the cost of isolation, i.e., adequate management systems are in place to ensure disease free broodstock and water exchange is biosecure. Without these the biosecurity of the closed system is nonexistent.

In comparison, open systems are relatively low cost and the relative availability of land in mangrove areas gives more opportunity to producers to simply extend the area of production once their ponds are infected. However, this has lead to the exponential increase of pathogens in the surrounding waters and wild crustacean populations leading to extensive clearing of mangroves to maintain production.

Decisions over disease management also lead to considerable economic risk as evidenced by the US \$4-6 billion loss of Penaeus monodon through Asian countries between 1992 and 2001 (Lightner 2005). International pressure for food quality and safety coupled with poor management decisions increased the risks associated with shrimp farming. To combat the increased prevalence of disease, producers increased their use of antibiotics. Poor application of these chemicals has led to the higher resistance of pathogens as well as higher concentrations of residual chemicals in exported shrimp. As many of these chemicals are restricted substances in the EU and US, producers have found themselves excluded from lucrative global markets (Bush and Oosterveer 2007). The scale and locality of risk in shrimp farming is therefore linked from local to global scales. The application of chemical substances may reduce the risks associated with diseases, but if unmanaged, may also increase producer's vulnerability to market regulation.

\section{Decision making under uncertainty}

The resilience of a household, i.e., its ability to maintain a viable livelihood, is comprised of a complex portfolio of assets and income streams, the continuation of which is subject to the capacity to make decisions under uncertainties associated with changing weather patterns, the risk of disease, market prices, and political change. At the same time, the resilience of the mangrove areas, on which the household depends, may be characterized by complex interactions within and between mangrove forests, estuaries, and coastal zones which are characterized by a high uncertainty from natural 
variation. Within such social-ecological systems decision making is an iterative process in which producers and other actors constantly adjust their livelihoods to changing conditions based on the assessment and reassessment of the stocks of assets and capabilities at their disposal, given environmental conditions (Marschke and Sinclair 2009). Before understanding the effectiveness of governance mechanisms to steer towards open or closed production systems, livelihoods need to be understood in the context of how decisions deal with risk under conditions of uncertainty.

Analyzing these iterative decision making processes under conditions of uncertainty moves beyond linear livelihood diversification models to focus on 'pathways' of decision making. Rather than measuring the success or failure of a livelihood relative to a predefined goal, these pathways comprise a series of iterative decision events based on external influences and environmental context (De Bruijn and Van Dijk 2004). Livelihoods are therefore understood in the context of external driving forces that determine the risk associated with acquiring adequate access and control over assets and capabilities. These external events may be environmental, such as local flood events or disease outbreaks, or social, such as changing dynamics with local credit and kinship relations or global market fluctuations (Marschke and Berkes 2006). Normative strategies such as diversification should be understood in terms of the wider context in which they can be fulfilled. Whether a producer can develop a successful closed or landscape integrated aquaculture system is therefore dependent on the wider context within which capacities and assets are operationalized.

In open landscape integrated systems the uncertainties of producers are largely based on daily, seasonal, and longer term environmental variability and local and domestic market fluctuations. To adapt to these external risks, producers make iterative decisions on how to use and adapt their capabilities and assets to change their aquaculture practices, diversify to other off-farm activities, or exit production all together. In doing so producers are able to offset the risks associated with shrimp production with gains in alternative activities. Shrimp producers across Southeast Asia who are successful with as few as one in eight shrimp crops, because of disease and market fluctuations, often avoid bankruptcy by offsetting these losses with income streams from alternative on and off- farm sources (Luttrell 2006, Hue and Scott 2008). The challenge is to identify the external social and environmental factors that enable or constrain producers and, given their endowment of assets and capabilities, understand how they avoid the risk of failure by making either pre-emptive or reactive decisions over production.

If producers are unable to develop a pre-emptive strategy, they are less able to either resist unfavorable change, mould events to minimize their exposure to change, or innovate ex post to take advantage of changed circumstances. Open landscape integrated farms, assuming they are small-scale and local in origin, may adapt under these circumstances through a range of coping strategies including communal mechanisms of insurance through social and familial support networks to mitigate risk and loss (Adger et al. 2005, Marschke and Berkes 2006, Bodin and Crona 2008). A more extreme response may be the decision to exit from farming and/or migrate for labor opportunities. If the catastrophic change in shrimp farming is due to disease outbreaks or acidified soils, then producers may decide to access new mangrove areas, so beginning the cyclical process of socialecological destruction so strongly associated with shrimp aquaculture in Southeast Asia. In comparison, closed-system farmers, assuming their farms are larger in scale and that they are unable to extend to new areas because of cost, may decide to close down their operations and shift their capital into new industries. Alternatively, assuming they are larger and/or wealthier, they may decide on a strategy of innovation to provide a pre-emptive and purposeful transformation to more secure production, or more desirable market advantages with higher returns.

As the level of production increases and their access to national, regional, and global markets improves, producers have considerable incentive to intensify. However, in doing so they must consolidate their time, effort, and financial resources, thereby reducing the diversity of their livelihood portfolios. Shrimp producers in Thailand who followed this path in the 1990s benefited with income streams of up to 15 to 16 times higher than their former diversified rice-based livelihoods (Flaherty et al. 1999, Flaherty et al. 2000). These systems may be less vulnerable to disease and environmental perturbation than landscape integrated systems if they can be successfully isolated. But the higher investment required for closed systems, their 
increased dependence on external inputs through international markets, and the vagaries of intensification exposes them to new risks. Recent examples include the billions of dollars lost as a result of WSD in the last decade and the volatility of export markets (Lightner 2005, Loc 2006). Governing shrimp production in order to steer producers toward either closed or open systems therefore requires an understanding of the external driving forces, both environmental and social, that set producers on specific decision making pathways and the implications these pathways have for the broader resilience of coastal social-ecological systems.

\section{Steering toward resilience}

Effective governance arrangements face the challenge of promoting resilient forms of shrimp production by facilitating producers to develop the capacity for both timely and adaptive responses that enable them to respond to external drivers of change. As state policy and legislation is less able to adapt to rapidly changing demand from global markets, shrimp production practice has expanded beyond the rate at which coastal ecosystems can maintain either social or ecological resilience (Armitage and Johnson 2006). Likewise, local natural resource management institutions, which have evolved through the long-term engagement of coastal communities, have also been eroded by rapid market integration or captured by political elites (Stonich and Bailey 2000, Hall 2004, Islam 2009). The two scenarios posited in this paper face considerably different challenges. However, steering towards either an open or closed system requires new ways of (re)engaging state, community, and marketbased institutions that have often until now supported the expansion and widely perceived mismanagement of coastal environments.

In recent years there has been a proliferation of new governance arrangements focused on the definition and enforcement of shrimp quality standards. Recent reviews of the various initiatives on offer reveal more than 30 sets of standards with varying objectives ranging from fair trade to organic and sustainable production (Corsin et al. 2007, WWF 2007). Most of the standards are combinations of state, such as Thai Quality Shrimp (see Oosterveer 2006), multilateral, such as The Consortium (see FAO et al. 2006), and nongovernmental organizations, such as the WWF Aquaculture
Dialogues (see WWF 2007). Likewise their enforcement has shifted sole responsibility for legitimacy away from the state to include private and NGO-based boards, review panels, and certification bodies. As these new governance arrangements become more common, the challenge for research is to determine how quality standards can be flexible enough to deal with the range of uncertainties producers face, while at the same time providing an equitable but rigorous steering mechanism toward sustainable production.

The system of provision for shrimp across the globe is set to change in response to the decision by large retailers in Europe to sell only environmentally certified seafood in their shops by 2012. This transforms sustainability-based quality standards from what is until now largely a voluntary labeling initiative to a system that has the potential to transform the shrimp industry. What implications this holds for producers is as yet unclear. Until now the majority of quality standards have been successful in countries with traceable, informationrich production systems. However, less success has been met in countries where producers have poorer capacity for compliance and the cost of certification is prohibitive (Klooster 2005, Guthman 2007, Islam 2008). Efficient systems for governing food safety and product related quality are already in place, but these extend predominantly to processing companies. It is highly likely that shifting regulation from the factory to the farm will require engaging, and in many cases redefining, the social and economic relations of production which determine the adaptive capacity of producers.

As environmental and social standards are adopted throughout the shrimp industry, a range of new capabilities will be required by producers to maintain market access. However, given the experiences of other sectors, such as forestry (Klooster 2005), it is unlikely that small-scale producers will be able to meet these requirements without more participatory implementation, monitoring, and evaluation. In landscape integrated systems, area-based certification methodologies may prove more effective to reduce the cost and more adequately account for the ecological interactions with surrounding coastal habitats. Managing the risk of these aquaculture systems requires new methodologies for including the uncertainty of environmental monitoring evaluation (Power 2007), including what are coming to be known as social or 'risk based' auditing methods. 
To increase compliance, these methodologies may seek better interaction with existing communal resource management arrangements that govern access to coastal resources such as water, tidal flows, and wild seed (Vandergeest 2007). In closed systems, environmental standards are likely to be more effective given their internally controlled and monitored production. Existing social standards based on UN and International Labour Organization conventions would remain adequate enough to cover the conditions of employees. However, more attention is needed to determine whether and how standards could evaluate grievances between surrounding communities over issues such as access to coastal resources.

In order to develop governance arrangements that can effectively steer producers to either closed or open systems we need to understand how producers, as well as market and state actors, respond to external drivers of change. Compared to the territorial and somewhat fossilized nature of state regulation, state and private quality standards have potential to provide timely response to rapidly expanding international markets and decisions of producers as they adapt to changing social, environmental, and economic circumstances. However, it is yet to be seen whether certification developed through lengthy deliberations with stakeholders, as currently seen with the WWF aquaculture dialogues (see Boyd et al. 2005), will be adaptive and inclusive enough over time. To effectively steer producers toward either closed or landscape integrated systems we need to better understand the interaction between state, market, and community based governance mechanisms, from local to global scales, to determine what combinations best foster resilience of coastal socialecological systems.

\section{CONCLUSION: AN EMERGING RESEARCH AGENDA}

The closed and landscape integrated scenarios provide a polar dichotomy that represent competing visions of rebuilding resilient tropical coastal environments. There are no definitive answers to whether either of them is better, nor can it be clearly outlined in general which scenario is more achievable or what the steps are toward achieving transitions to more resilient farming and use of coastal resources. Instead, there is likely to be a range of systems along a spectrum between these two poles that are more sustainable than current systems. This paper has elaborated the complexity of shrimp production systems and the requirements of rebuilding social-ecological resilience in coastal areas. The first challenge is to understand the complexities and uncertainties of these systems to coordinate decision making at farm, community, and regional scales to mitigate existing and potential effects. The second challenge is to ensure that any governance mechanism that seeks to coordinate these decisions are able to provide strategic simplifications that adequately translate and communicate the interlinkages between the resilience of ponds, coastal ecosystems, and the communities that exploit them.

To address these challenges we now turn to the implications the two scenarios hold for various disciplinary approaches and outline a set of key questions for ongoing research. In short, we ask how research in ecology, epidemiology, and shrimp farm management, livelihoods and global markets can contribute to our understanding of how to rebuild coastal shrimp aquaculture as a resilient socialecological system in the context of decision making at all levels of governance.

Ecosystem health and fishery productivity in coastal waters are dependent on functioning coastal mangrove forest. Based on our current understanding it is not clear whether open landscape integrated shrimp farming can have a positive or neutral effect on biodiversity and the productive functions of the coastal zone. Failure to detect and respond to effects may be because of a lack of capacity to engage with and understand the perceptions of stakeholders and/or the inherent difficulties in detecting effects and attributing changes on coastal fish communities to multiple causes (Van Densen 2001, van Zwieten et al. 2006). A central question is at what scale and extent can shrimp farming be successfully integrated in mangrove ecosystems without affecting the production function of ponds and surrounding biodiversity? What indicators as well as reference and target levels can be developed for this? From a biodiversity perspective a negative effect may be tolerated if effects do not change the adaptive capacity of the mangrove ecosystems to maintain the resilience of coastal environments and their associated productive capacity. Alternatively, the most effective means of ensuring the ecological functions of mangrove areas is to develop closed systems outside mangrove areas. 
The diversity of open landscape integrated systems, although not mitigating uncertainty, may be more likely to advance both the social and ecological capacity for self-organization and increased disease resilience, though it is unlikely that WSD will be contained within these approaches to aquaculture development. Fostering internal self-organization in these systems, however, often requires drastic changes through a process in production practices. This may come at a cost to short-term income and therefore stay out of reach of a large proportion of producers. Still, the question remains why the practice of silvofisheries, landscape integrated shrimp farming, is not widespread in Southeast Asia and mangroves continue to be lost (Tong et al. 2004). Alternatively, questions also remain as to whether closed systems offer a possible avenue for disease resilient shrimp production. These systems may be better protected from pathogens, but also highly engineered systems are never fail-safe and lead to an ever increasing need for external intervention, e.g., screening of seeds, certification of hatcheries, that increases complexity and vulnerability. Investing in this form of production may force further investment in engineered solutions and complex maintenance systems to keep-up the security and resilience of the system.

The resilience of producer's livelihoods is dependent on their capacity to make decisions in response to external forces. Coastal areas inhabited by shrimp ponds are in flux, based on the compounded factors of disease, changes in ecological function, and fluctuation in trade. Given this, questions remain as to whether producers are able to meet the increasingly complex demands set out for integrated sustainable shrimp production after the mangrove areas have deteriorated by their production system. This requires asking what the internal and external factors are that would drive producers to: (1) develop alternative aquaculture systems that are ecologically, financially, and socially sound; (2) diversify production into new areas; or (3) seek employment in intensive farms located outside of mangrove areas.

The international nature of the shrimp trade and the perceived failure of governments to deal adequately with the negative social and environmental effects of shrimp production have led to new forms of governance. As governance shifts from local to global and from the state to the market, it is increasingly important to develop governance arrangements that can adequately deal with the drivers of change in complex systems and promote environmentally and socially desirable outcomes. How effective new governance arrangements such as state and private quality standards can be depends on the degree to which they can steer producers to new forms of production. Research therefore needs to focus on the extent to which emerging governance arrangements can translate the complexity of socialecological systems outlined above into standards or regulations that can foster the producers to amend or change their practices. This means we need to better understand what practices need to be changed, but also who is more likely to develop the necessary skills needed to gain and maintain access to international markets: small-scale landscape integrated farmers or industrial-scale closed system producers? Is there an inherent bias for intensive production systems over extensive systems? If so, what new roles should state and private sector actors fill in terms of extension and enforcement? Asking such questions might even lead us to ask whether it is possible to promote social and ecological resilience without difficult trade-offs.

Responses to this article can be read online at: http://www.ecologyandsociety.org/voll5/iss2/art15/ responses/

\section{Acknowledgments:}

The paper was developed after a series of meetings during summer, winter, and spring 2007-2008 with Rini Kusumawati, Bambang Gunawan, Audrie Siahainenia, Desrina Haryadi, Tran Thi Thu Ha, Tran Thi Phung Ha, Nguyen Huu Nghia, Tran Thi Tuyet Hoa, Tuyen Ngo Xuan, and Eleonora Tendencia, PhD students of the RESCOPAR program, and their supervisors from Wageningen University in which we discussed the concepts outlined in the paper. They are all thanked for their contributions to the discussion. The Interdisciplinary Research Fund (INREF) of Wageningen University funded the research. Paul A.M. van Zwieten and Roel Bosma received additional funding through the MANGROVE research program (EU-FP6-STREP contract 003697). 


\section{LITERATURE CITED}

Aquaculture Certification Council (ACC). 2005. Aquaculture facility certification: Guidelines for BAP standards. Aquaculture Certification Council, Kirkland, Washington, USA .

Adger, W. N. 2000. Social and ecological resilience: Are they related? Progress in Human Geography 24:347-364.

Adger, W. N., T. P. Hughes, C. Folke, S. Carpenter, and J. Rockstrom. 2005. Socialecological resilience to coastal disasters. Science 309:1036-1039.

Adger, W. N., P. M. Kelly, and N. H. Ninh, editors. 2001. Living with environmental change: social vulnerability, adaptation and resilience in Vietnam. Routledge, London, UK.

Alongi, D. M. 2002. Present state and future of the world's mangroves. Environmental Conservation 29:331-349.

Armitage, D., and D. Johnson. 2006. Can resilience be reconciled with globalization and the increasingly complex conditions of resource degradation in Asia coastal regions? Ecology and Society 11(1): 2. [online] URL: http://www.ecology andsociety.org/vol1/iss1/art2/.

Armitage, D., M. Marschke, and R. Plummer. 2008. Adaptive co-management and the paradox of learning. Global Environmental Change 18:86-98.

Avnimelech, Y., and G. Ritvo. 2003. Shrimp and fish pond soils: processes and management. Aquaculture 220(1-4):549-567.

Aquaculture Certification Council (ACC). 2005. Aquaculture facility certification: guidelines for BAP standards. Aquaculture Certification Council, Kirkland, Washington, USA.

Bagarinao, T. U., and J. H. Primavera. 2005. Code of practice for sustainable use of mangrove ecosystems for aquaculture in southeast Asia. Southeast Asian Fisheries Development Center (SEAFDEC), Aquaculture Department, Iloilo, Philippines.

Barbier, E. B., and M. Cox. 2004. An economic analysis of shrimp farm expansion and mangrove conversion in Thailand. Land Economics 80:389-407.

Béné, C. 2005. The good, the bad and the ugly. Development Policy Review 23:585-614.

Berkes, F., J. Colding, and C. Folke, editors. 2003. Navigating social-ecological systems: building resilience for complexity and change. Cambridge University Press, Cambridge, UK.

Berkes, F., and C. Folke, editors. 1998. Linking social and ecological systems: management practices and social mechanisms for building resilience. Cambridge University Press, Cambridge, UK.

Beveridge M. C. M., A. Wahab, and S. Dewan. 1994. Effects of daily harrowing on pond soil and water nutrient levels and on rohu fingerling production. Progressive Fish-Culturist 56:282-287.

Binh, C. T., M. J. Phillips, and H. Demaine. 1997. Integrated shrimp-mangrove farming systems in the Mekong Delta of Vietnam. Aquaculture Research 28:599-610.

Bodin, Ö., and B. I. Crona. 2008. Management of natural resources at the community level: exploring the role of social capital and leadership in a rural fishing community. World Development 36:2763-2779.

Boyd, C., A. McNevin, J. Clay, and H. Johnson. 2005. Certification issues for some common aquaculture species. Reviews in Fisheries Science 13:231-279.

Boyd, C. E., and J. W. Clay. 2002. Evaluation of Belize aquaculture, Ltd: a superintensive shrimp aquaculture system in Belize. World BankB/ NACA/WWF/FAO Consortium Program on Shrimp Farming and the Environment.

Bush, S. R., and P. Oosterveer. 2007. The missing link: intersecting governance and trade in the space of place and the space of flows. Sociologia Ruralis 47:384-400.

Bush, S. R. 2010. Governing 'spaces of interaction' for sustainable fisheries. Tijdschrift voor Sociale en Economische Geografie 101:305-319.

Cash, D. W., and S. C. Moser. 2001. Linking global and local scales: designing dynamic assessment and 
management processes. Global Environmental Change 10: 109-120.

Corsin, F., S. J. Funge-Smith, and J. Clausen. 2007. A qualitative assessment of standards and certification schemes applicable to aquaculture in the Asia-Pacific region. RAP Publication 2007/25. FAO Regional Office for Asia and the Pacific, Bangkok, Thailand.

Costanza, R. 2003. A vision of the future of science: reintegrating the study of humans and the rest of nature. Futures 35:651-671.

De Bruijn, M., and H. Van Dijk. 2004. The importance of socio-cultural differences and of pathway analysis for understanding local actors in A. J. Dietz, R. Ruben, and A. Verhagen, editors. The impact of climate change on drylands. Springer, Dordrecht, The Netherlands.

Eggleton, M. A., K. B. Gido, W. J. Matthews, and G. D. Schnell. 2004. Assessment of anthropogenic influences on littoral zone aquatic communities of Lake Texoma, Oklahoma Texas, USA. Ecohydrology and Hydrobiology 4:103-117.

Food and Agriculture Organization(FAO). 2009. The State of world fisheries and aquaculture (Sofia), 2008. Food and Agriculture Organization of the United Nations, Rome, Italy.

Food and Agriculture Organization (FAO), Network of Aquaculture Centres in Asia-Pacific (NACA), United Nations Environment Programme (UNEP), World Bank Group (WB), and the World Wildlife Fund (WWF). 2006. International principles for responsible shrimp farming. Organization of the United Nations (FAO), the Network of Aquaculture Centres in Asia-Pacific (NACA), United Nations Environment Programme (UNEP), the World Bank Group (WB), and the World Wildlife Fund (WWF), Bangkok, Thailand.

Foreign Investment Advisory Service (FIAS). 2006. Improving Indonesia's competitiveness: case study of textile and farmed shrimp industries. Volume 1. Foreign Investment Advisory Service, International Finance Corporation and World Bank.

Fitzgerald, W. J. 2002. Silvofisheries: integrated mangrove forest aquaculture systems. in B. A.
Costa-Pierce, editor, Ecological Aquaculture: The Evolution of a Blue Revolution. Blackwell Science Ltd, Oxford, UK.

Flaherty, M., B. Szuster, and P. Miller. 2000. Low salinity inland shrimp farming in Thailand. Ambio 29:174-179.

Flaherty, M., P. Vandergeest, and P. Miller. 1999. Rice paddy or shrimp pond: tough decisions in rural Thailand. World Development 27:2045-2060.

Flegel, T. W. 2006. Detection of major penaeid shrimp viruses in Asia, a historical perspective with emphasis on Thailand. Aquaculture 258: 1-33.

Folke, C. 2006. Resilience: the emergence of a perspective for social-ecological systems analysis. Global Environmental Change 16:253-267.

Folke, C., S. Carpenter, T. Elmqvist, L. Gunderson, C. S. Holling, and B. Walker. 2002. Resilience and sustainable development: building adaptive capacity in a world of transformations. Ambio 31:437-440.

GlobalG.A.P. 2007. Integrated farm assurance: documents shrimp (English). [online] URL: http:// www.globalgap.org/cms/front content.php?idart=378 \&idcat=48 \&lang=1 \&client=1.

Guthman, J. 2007. The Polanyian way? Voluntary food labels as neoliberal governance. Antipode 39:456-478.

Hall, D. 2003. The international political ecology of industrial shrimp aquaculture and industrial plantation forestry in southeast Asia. Journal of Southeast Asian Studies 34:251-264.

Hall, D. 2004. Explaining the diversity of southeast Asian shrimp aquaculture. Journal of Agrarian Change 4:315-335.

Hindell, J. S., and G. P. Jenkins. 2005. Assessing patterns of fish zonation in temperate mangroves, with emphasis on evaluating sampling artefacts. Marine Ecology Progress Series 290:193-205.

Holling, C. S. 1973. Resilience and stability of ecological systems. Annual Review of Ecology and Systematics 4:1-23. 
Holling, C. S. 2001. Understanding the complexity of economic, ecological, and social systems. Ecosystems 4: 390-405.

Howitt, R. 1998. Scale as relation: musical metaphors of geographical scale. Area 30:49-58.

Hue, L. T. V., and S. Scott. 2008. Coastal livelihood transitions: socio-economic consequences of changing mangrove forest management and land allocation in a commune of central Vietnam. Geographical Research 46:62-73.

Iles, A. 2007. Making the seafood industry more sustainable: creating production chain transparency and accountability. Journal of Cleaner Production 15(6):577-589.

Islam, M. S. 2008. From pond to plate: towards a twin-driven commodity chain in Bangladesh shrimp aquaculture. Food Policy 33(3):209-223.

Islam, M. S. 2009. In search of white gold: environmental and agrarian changes in rural Bangladesh. Society and Natural Resources 22:66-78.

Kautsky, N., P. Ronnback, M. Tedengren, and M. Troell. 2000. Ecosystem perspectives on management of disease in shrimp pond farming. Aquaculture 191:145-161.

Klooster, D. 2005. Environmental certification of forests: the evolution of environmental governance in a commodity network. Journal of Rural Studies 21:403-417.

Kongkeo, H. 1997. Comparison of intensive shrimp farming systems in Indonesia, Philippines, Taiwan and Thailand. Aquaculture Research 28:789-796.

Lebel, L., J. M. Anderies, B. Campbell, C. Folke, S. Hatfield-Dodds, T. P. Hughes, and J. Wilson. 2006. Governance and the capacity to manage resilience in regional social-ecological systems. Ecology and Society 11(1): 19. [online] URL: http: //www.ecologyandsociety.org/vol11/iss1/art19/.

Lebel, L., N. H. Tri, A. Saengnoree, S. Pasong, U. Buatama, and L. K. Thoa. 2002. Industrial transformation and shrimp aquaculture in Thailand and Vietnam: pathways to ecological, social, and economic sustainability. AMBIO: A Journal of the Human Environment 31(4):311-323.

Levin, S. A. 1998. Ecosystems and the biosphere as complex adaptive systems. Ecosystems 1:431-436.

Lightner, D. V. 2005. Biosecurity in shrimp farming: pathogen exclusion through use of spf stock and routine surveillance. Journal of The World Aquaculture Society 36:229-248.

Lightner, D. V., K. W. Hasson, B. L. White, and R. M. Redman. 1998. Experimental infection of western hemisphere penaeid shrimp with Asian White Spot Syndrome Virus and Asian yellow head virus. Journal of Aquatic Animal Health 10:271-281.

Loc, V. T. T. 2006. Seafood supply chain quality management: the shrimp supply chain quality improvement perspective of seafood companies in the Mekong Delta, Vietnam. University of Groningen, Groningen, The Netherlands.

Loneragan, N. R., N. Ahmad Adnan, R. M. Connolly, and F. J. Manson. 2005. Prawn landings and their relationship with the extent of mangrove and shallow waters in western peninsular Malaysia. Estuarine, Coastal and Shelf Science 63.

Luttrell, C. 2006. Adapting to aquaculture in Vietnam: Securing livelihoods in a context of change in two coastal communities in C. T. Hoanh, T. P. Tuong, J. W. Gowing and B. Hardy, editors. Environment and livelihoods in tropical coastal zones. CAB International, Oxford, UK.

Macintosh, D. 1998. Mangroves and coastal aquaculture sustainability. Pages 242-251 In Aquaculture Sustainability and the Environment. Report on a regional study and workshop. ADB/ NACA, Bangkok, Thailand.

Macintosh, D. J., E. C. Ashton, and S. Havanon. 2002. Mangrove rehabilitation and intertidal biodiversity: a study in the Ranong mangrove ecosystem, Thailand. Estuarine Coastal and Shelf Science 55:331-345.

Manson, F. J., N. R. Loneragan, B. D. Harch, G. A. Skilleter, and L. Williams. 2005a. A broad- 
scale analysis of links between coastal fisheries production and mangrove extent: a case-study for northeastern Australia. Fisheries Research 74:69-85.

Manson, F. J., N. R. Loneragan, G. A. Skilleter, and S. R. Phinn. 2005b. An evaluation of the evidence for linkages between mangroves and fisheries: a synthesis of the literature and identification of research directions. Oceanography and Marine Biology: an Annual Review 43: 483 513.

Marschke, M., and A. J. Sinclair. 2009. Learning for sustainability: participatory resource management in Cambodian fishing villages. Journal of Environmental Management 90:206-216.

Marschke, M. J., and F. Berkes. 2006. Exploring strategies that build livelihood resilience: a case from Cambodia. Ecology and Society 11: 42 [online] URL: http://www.ecologyandsociety.org/vol11/iss1/ $\underline{\operatorname{art} 42 / .}$.

Meijer, L. E., and Y. Avnimelech. 1999. On the use of micro-electrodes in fish pond sediments. Aquacultural Engineering 21:71-83.

Mumby, P. J., A. J. Edwards, J. E. Arias Gonzales, K. C. Lindeman, P. G. Blackwell, A. Gall, M. I. Gorczynska, A. R. Harborne, C. L. Pescod, H. Renken, C. C. C. Wabnitz, and G. Llewellyn. 2003. Mangroves enhance the biomass of coral reef fish communities in the Caribbean. Nature 427:533-536.

Nadasdy, P. 2007. Adaptive co-management and the gospel of resilience. in D. Armitage, F. Berkes and N. Doubleday. Adaptive co-management, collaboration, learning, and multi-level governance. UBC Press, Vancouver, Canada

Neiland, A. E., N. Soley, J. B. Varley, and D. J. Whitmarsh. 2001. Shrimp aquaculture: economic perspectives for policy development. Marine Policy 25:265-279.

Nicholls, R. J., and J. Branson. 1998. Coastal resilience and planning for an uncertain future: an introduction. The Geographical Journal 164:255-258.

Norgaard, R. B. 1994. Development betrayed; the end of progress and a coevolutionary revisioning for the future. Routledge, New York, NY, USA.
Odum, E. P. 1975. Ecology: the link between the natural and social sciences. Second edition. Holt, Rinehart \& Winston, London, UK.

Oosterveer, P. 2006. Globalization and sustainable consumption of shrimp: consumers and governance in the global space of flows. International Journal of Consumer Studies 30:465-476.

Oosterveer, P. 2007. Global governance of food production and consumption: issues and challenges. Edward Elgar, Cheltenham, U.K.

Otoshi, C. A., C. M. Holl, D. R. Moss, S. M. Arce, and S. M. Moss. 2006. Super-intensive RAS trial yields encouraging shrimp harvest at Oceanic Institute. Global Aquaculture Advocate 9:64-65.

Otoshi, C. A., L. R. Tang, D. R. Moss, S. M. Arce, C. M. Holl, and S. M. Moss. 2009. Performance of Pacific white shrimp, Penaeus (Litopenaeus) Vannamei, cultured in biosecure, super-intensive, recirculating aquaculture systems. in C. L. Browdy and D. E. Jory, editors. The rising tide. Proceedings of the World Aquaculture Society on sustainable shrimp farming in Veracruz, Mexico. World Aquaculture Society.

Phillips, M. J. 2006. Regional study on economic opportunities in shrimp farming in West Africa: an initial review. Technical Working Paper 3: Environmental aspects and sustainable development. Prepared for the Sahel and West Africa Club Organisation for Economic Co-operation and Development (OECD). Bangkok, Thailand.

Phuoc L. H., M. Corteel, N. C. Thanh, H. Nauwynck, M. Pensaert, V. Alday-Sanz, W. V. den Broeck, P. Sorgeloos, and P. Bossier. 2009. Effect of dose and challenge routes of Vibrio spp. on co-infection with white spot syndrome virus in Penaeus vannamei. Aquaculture 290:61-68.

Pittman, S. J., C. A. McAlpine, and K. M. Pittman. 2004. Linking fish and prawns to their environment: a hierarchical landscape approach. Marine Ecology Progress Series 283:233-254.

Power, M. 2007. Organized uncertainty: designing a world of risk management. Oxford University Press, Oxford, UK.

Primavera, J. H. 1997. Socio-economic impacts of shrimp culture. Aquaculture Research 28:815-827. 
Primavera, J. H. 2000. Integrated mangrove aquaculture systems in Asia. Integrated Coastal Zone Management Autumn:121-128.

Primavera, J. H. 2006. Overcoming the impacts of aquaculture on the coastal zone. Ocean and Coastal Management 49:531-545.

Primavera J. H., and J. M. A. Esteban. 2008. A review of mangrove rehabilitation in the Philippines: successes, failures and future prospects. Wetlands Ecology and Management 16:345-358.

Stonich, S. C., and C. Bailey. 2000. Resisting the blue revolution: contending coalitions surrounding industrial shrimp farming. Human Organization 59:23-36.

Suzan, G., J. T. Giermakowski, E. Marce, H. Suzan-Azpiri, B. Armien, and T. L. Yates. 2006. Modelling hantavirus reservoir species dominance in high seroprevalence areas on the Azuero Peninsula of Panama. American Journal of Tropical Medicine and Hygiene 74:1103-1110.

Suzan, G., E. Marce, J. T. Giermakowski, B. Armien, J. Pascale, J. Mills, G. Ceballos, A. Gomez, A. A. Aguirre, J. Salazar-Bravo, A. Armien, R. Parmenter, and T. Yates. 2008. The effect of habitat fragmentation and species diversity loss on hantavirus prevalence in Panama. Annals of the New York Academy of Sciences 1149:80-83

Tendencia, E. A., R. H. Bosma, R. Usero, and A. J. J. Verreth. 2009. Effect of rainfall and atmospheric temperature on the prevalence of whitespot syndrome virus (WSSV) in pond cultured Penaeus monodon. Aquaculture Research 40:1-4.

Tong, P. H. S., Y. Auda, J. Populus, M. Aizpuru, A. Habshi, and F. Blasco. 2004. Assessment from space of mangroves evolution in the Mekong Delta in relation to extensive shrimp farming. International Journal of Remote Sensing 25:4795-4812.

Vaiphasa, C., W. F. de Boer, A. K. Skidmore, S. Panitchart, T. Vaiphasa, N. Bamrongrugsa, and P. Santitamnont. 2007. Impacts of shrimp pond waste materials on mangrove growth and mortality: a case study from Pak Phanang, Thailand. Hydrobiologia 591:47-57.
Valiela, I., J. L. Bowen, and J. K. York. 2001. Mangrove forests: one of the world's threatened major tropical environments. BioScience 51:807-815.

Van Densen, W. L. T. 2001. On the perception of time trends in resource outcome: its importance in fisheries co-management, agriculture and whaling. Twente University, Enschede, The Netherlands.

van Zwieten, P. A. M., A. S. Sidik, Noryadi, I. Suyatna, and Abdunnur. 2006. Aquatic food production in the coastal zone: data-based perceptions on the trade-off between mariculture and fisheries production of the Mahakam Delta and Estuary, East Kalimantan, Indonesia. In C. $\mathrm{T}$. Hoanh, T. P. Tuong, J. W. Gowing and B. Hardy, editors. Environment and livelihoods in tropical coastal zones: managing agriculture - fishery aquaculture conflicts. CABI Publishing, Oxford, UK.

Vandergeest, P. 2007. Certification and communities: alternatives for regulating the environmental and social impacts of shrimp farming. World Development 35:1152-1171.

Vlak, J. M., J. R. Bonami, T. W. Flegel, G. H. Kou, D. V. Lightner, C. F. Lo, P. C. Loh, and P. W. Walker. 2005. Nimaviridae. Pages 187-192 in C. M. Fauquet, M. A. Mayo, J. Maniloff, U. Desselberger, and L. A. Ball, editors. Virus Taxonomy. Eighth Report of the International Committee on Taxonomy of Viruses. Elsevier, Amsterdam, The Netherlands.

Walker, B., C. S. Holling, S. R. Carpenter, and A. P. Kinzig. 2004. Resilience, adaptability and transformability in social-ecological systems. Ecology and Society 9: 5 [online] URL: http://www. ecologyandsociety.org/vol9/iss2/art5/.

WWF 2007. Aquaculture dialogues overview. WWF International. [online] URL: http://Www.Wo rldwildlife.org/what/globalmarkets/aquaculture/ aquaculturedialogues.html

Yu, R., P. Leung, and P. Bienfang. 2006. Optimal production schedule in commercial shrimp culture. Aquaculture 254:426-441. 